\title{
11: 69726917-69731144
}

National Cancer Institute

\section{Source}

National Cancer Institute. 11: 69726917-69731144. NCI Thesaurus. Code C42244.

Physical location of FADD_Gene 